Dr DRAGAN CVETKOVIĆ, muzejski savetnik

Muzej žrtava genocida

Beograd, Trg Nikole Pašića 11, Republika Srbija

vecadzigy@yahoo.com

originalan naučni rad

UDK: 94:341.485(=411.16)(497.11)"1941/1944"

primljeno: 11. jul 2017.

314.117-058.65(=411.16)(497.11)"1941/1944"

prihvaćeno: 15. novembar 2017.

343.819.5(=411.16)(497.11)"1941/1944"

DOI: 10.29362/IST20VEKA.2018.1.CVE.69-92

\title{
LOGORI TOPOVSKE ŠUPE I SAJMIŠTE KAO CENTRALNA MESTA HOLOKAUSTA U OKUPIRANOJ SRBIJI - NUMERIČKO ODREĐENJE I KVANTITATIVNA ANALIZA
}

APSTRAKT: Članak predstavlja pokušaj da se na osnovu delimično revidiranog popisa „Žrtve rata 1941-1945“ prikaže centralna uloga logora Topovske šupe i Sajmište (Judenlager Semlin) u uništenju jevrejske zajednice u okupiranoj Srbiji. U radu je razmatrana teritorijalna pripadnost stradalih Jevreja, polna, starosna i profesionalna struktura njihovih gubitaka u ova dva logora, te je prikazan udeo gubitaka iz ova dva logora u ukupnim gubicima jevrejske zajednice.

KLJUČNE REČI: Holokaust, Jevreji, okupirana Srbija, regioni, polna, starosna i profesionalna struktura, koncentracioni logori, Topovske šupe, Sajmište

Oslanjajući se na teror i represiju kao glavne metode vladanja pokorenim područjima Nemci su formirali sistem logora kojima su podržavali te metode, odnosno koji su imali ulogu u njihovom sprovođenju. Na području Srbije pod nemačkom vojnoupravnom komandom (dalje okupirana Srbija) formiran je niz logora različitih tipova i namena. ${ }^{1}$ Među njima su logori za Jevreje predstavljali posebnu kategoriju, kao deo programa njihovog uništenja. Holokaust, kao najekstremniji oblik do sada poznatog genocida i prva pojava nekih vrsta zločinačkih ubistava i zločinačkog mišljenja, imao je na prostoru izdeljene Jugoslavije niz specifičnosti u „rešavanju jevrejskog pitanja“, kao ni u jednom drugom delu Evrope, ali se time nikako ne izdvaja iz opšteg konteksta stradanja evropskih Jevreja. Pored svih specifičnosti holokausta u Jugoslaviji, onaj sproveden na teritoriji okupirane Srbije je bio najsličniji holokaustu sprovođenom u evropskim zemljama, sa nemačkim okupacionim režimom kao njegovim inspirato-

\footnotetext{
${ }^{1}$ Opširnije: Milan Koljanin, „Represija kao sistem - logori u okupiranoj Srbiji“, Heretikus, br. 1, (2007), 157-171.

2 Yehuda Bauer, „Is the Holocaust explicable“, u: Израелско-српска научна размена у проучавању холокауста / Israeli-Serbian academic exchange in Holocaust research, ур. Јован Мирковић (Београд: Музеј жртава геноцида, 2008), 149.
} 
rom, nosiocem u njegovom planiranju i sprovođenju, te kao jedinim egzekutorom. Kolaboracionisti sa okupirane teritorije pružali su pomoć Nemcima u pojedinim delovima sprovođenja programa uništenja Jevreja.

Holokaustu na teritoriji okupirane Srbije, kao i u logorima koji su poslužili kao sredstvo za njegovo sprovođenje, posvećen je niz radova u domaćoj i inostranoj istoriografiji, kao centralna ili prateća tema, a među kojima se, svakako, izdvaja monografija o logoru na Sajmištu. ${ }^{3}$ U istoriografiji je već ukazano na manjkavosti u postojećim saznanjima o logorima prvenstveno $u$ unutrašnjoj strukturi logoraša (ko su, koje nacionalnosti, odakle su, koliko su bili stari, kog su pola, kog zanimanja?). ${ }^{4}$ Stoga ovaj rad nastao na osnovu delimično revidiranog popisa „Žrtve rata $1941-1945^{\prime \prime}$ iz 1964. godine ${ }^{5}$ ima cilj da delimično otkloni nedostatke, odnosno proširi dosadašnja saznanja o dva logora za Jevreje koji su se nalazili u Beogradu, prvenstveno u pogledu unutrašnje strukture stradalih.

Kod Jevreja sa teritorije okupirane Srbije ${ }^{6}$ stradalih u holokaustu do sada su delimičnom revizijom popisa „Žrtve rata $1941-1945^{\prime \prime}$ poimenično identifikovane 6.254 osobe. $^{7}$ Shodno odluci Nemaca prema kojoj su kolektivno bili određeni za uništenje, Jevreji iz okupirane Srbije bili su ubijeni u manje od 365 dana tokom prve dve godine rata. U stradanju u poslednje tri godine rata, nakon kulminacije holokausta na teritoriji okupirane Srbije, život su izgubili malobrojni Jevreji u logoru Banjica ${ }^{8}$ i oni pripadnici jevrejske zajednice koji su neuspešno pokušali da utočište pronađu na drugim teritorijama podeljene Jugoslavije ili u inostranstvu. ${ }^{9}$

\footnotetext{
${ }^{3}$ Milan Koljanin, Nemački logor na Beogradskom sajmištu 1941-1944 (Beograd: ISI, 1992). Za kraći pregled značajnijih radova videti: Милан Кољанин, „Истраживање холокауста у Југославији“, у: Израелско-српска научна размена..., 264-273; Јован Ћулибрк, Историографија холокауста у Југославији (Београд: ПБФ и ИТИ, 2011).

${ }^{4}$ M. Koljanin, „Represija kao sistem - logori u okupiranoj Srbiji“, 158, 167-169.

${ }^{5}$ Opširnije o popisu „Žrtve rata“: Mr Dragan Cvetković, „Gubici pripadnika partizanskog pokreta sa teritorije Jugoslavije 1941-1945“ (doktorska disertacija, Univerzitet u Beogradu, Filozofski fakultet, Odeljenje za istoriju, 2016), 6-10.

${ }^{6}$ U obzir su uzeti Jevreji koji su bili jugoslovenski državljani, odnosno Jevreji koji su u trenutku izbijanja rata mesto boravka imali na teritoriji na kojoj je uspostavljena nemačka okupaciona uprava. Pored njih na teritoriji okupirane Srbije stradali su i Jevreji iz drugih delova Jugoslavije, kao i Jevreji iz evropskih zemalja koji su se kao legalni imigranti, „neželjeni turisti“ ili izbeglice našli na njenoj teritoriji i podelili sudbinu sa domaćim Jevrejima. Opširnije videti: Milan Ristović, „Jugoslavija i jevrejske izbeglice 1938-1941“, Istorija 20. veka, br. 1, (1996), 21-43; Andrej Mitrović, ur., Kladovo transport / The Kladovo transport, Zbornik radova, (Beograd: JIM, 2006).

${ }^{7}$ Arhiv Jugoslavije (AJ), fond 179, Popis „Žrtve rata 1941-1945“ iz 1964. godine; Arhiv Muzeja žrtava genocida (AMŽG), fond Popis „Žrtve rata 1941-1945“ i Baza podataka „Žrtve rata 1941-1945“.

${ }^{8}$ Opširnije o stradanju Jevreja sa teritorije okupirane Srbije u logoru Banjica: Branka Prpa, gl. i od. ur., Logor Banjica, Logoraši (Beograd: Istorijski arhiv Beograda, 2009).

${ }^{9}$ Opširnije o uspešnim i neuspešnim pokušajima spasavanja od holokausta: Милан Ристовић, $У$ потрази за уточиштем, Југословенски Јевреји у бекству од холокауста 1941-1945 (Београд: Службени лист СРЈ, 1998).
} 
Tabela 1: Okupirana Srbija, Jevreji-godine stradanja

\begin{tabular}{|c|c|c|c|c|c|c|c|c|c|c|c|}
\hline $\begin{array}{c}\text { Okupirana } \\
\text { Srbija }\end{array}$ & Ukupno & 1941 & $\%$ & 1942 & $\%$ & 1943 & $\%$ & 1944 & $\%$ & 1945 & $\%$ \\
\hline Ukupno & 6.254 & 2.103 & 33,62 & 4.007 & 64,07 & 87 & 1,39 & 51 & 0,81 & 6 & 0,09 \\
\hline
\end{tabular}

AMŽG, Baza podataka „Žrtve rata 1941-1945“

Brutalnost holokausta na okupiranoj teritoriji se vidi u tome što je $97,69 \%$ od svih stradalih život izgubilo tokom prve dve godine rata, $\mathrm{s}$ time što ih je trećina ubijena u drugoj polovini 1941. godine, ${ }^{10}$ dok su dve trećine stradale tokom naredne godine, od kojih je najveći deo izgubio život u prva četiri i po meseca 1942. godine. ${ }^{11}$ Time je stopa smrtnosti, s obzirom na dvostruko duži period stradanja u 1942. godini, bila jednaka, što ukazuje na nesmanjenu težnju Nemaca da Jevreje potpuno unište. Proces uništenja jevrejske zajednice u okupiranoj Srbiji praktično je 1942. godine bio okončan, tako da je pretrpljeni gubitak Jevreja u 1943. godini bio 49,06 puta manji nego u prethodnoj. Svega 2,31\% od stradalih Jevreja okupirane Srbije izgubilo je živote $u$ poslednje tri godine rata, tako da je njihov gubitak $u$ tom periodu bio realno 65,78 puta manji nego u prve dve godine.

Nastanjeni u svim regionima ${ }^{12}$ okupirane Srbije, ${ }^{13}$ Jevreji su svuda trpeli gubitke. Jevreji iz Beogradskog regiona, kao najveća zajednica na teritoriji okupirane Srbije, predstavljali su gotovo tri petine gubitaka, sledili su ih sunarodnici iz Banata koji su činili više od četvrtine gubitaka, dok je iz ostalih 8 regiona poticala šestina stradalih Jevreja. Njihovo stradanje nije bilo uvek u skladu sa zastupljenošću u okviru nacionalnog korpusa Jevreja iz različitih delova teritorije.

${ }^{10}$ Sa pojedinačnim likvidacijama ili ubijanjem malih grupa Jevreja otpočelo se ubrzo nakon okupacije, u prvim danima jula. Od stradalih Jevreja 1941. godine sa poznatim datumom smrti 90,41\% izgubilo je živote tokom oktobra i novembra (1.885).

${ }^{11}$ Zapravo, najveći deo Jevreja sa teritorije okupirane Srbije stradalih 1942. godine izgubio je život u kratkom periodu od tri meseca, marta, aprila i maja. Oni predstavljaju 89,08\% gubitaka od svih sa poznatim datumom stradanja u toj godini.

${ }^{12}$ Regione treba posmatrati isključivo kao geografske celine pošto oni u tom periodu nisu postojali kao administrativne jedinice; nastali su iz potrebe da se lakše sagleda stradanje stanovništva i omogući komparativno prikazivanje pretrpljenih gubitaka. Regioni su obuhvatali opštine ili njihove delove prema administrativnoj podeli iz 1964. godine.

${ }^{13}$ Prema popisu stanovništva iz 1931. godine 12.648 Jevreja je predstavljalo $0,33 \%$ stanovništva teritorije koja se 10 godina kasnije našla pod okupacijom. Od Jevreja, sa teritorije koja je podelom Jugoslavije postala okupirana Srbija, 1931. godine 62,51\% živelo je u Beogradskom regionu (7.906), 29,39\% u Banatu (3.717) i 8,10\% u ostalih osam regiona (1.025). U Upravi grada Beograda 1931. godine živelo je 8.936 pripadnika jevrejske zajednice, od kojih je 507 bilo nastanjeno u Pančevu, a 523 u Zemunu, pa ih prema ratnoj podeli teritorije treba posmatrati kao banatske (u okviru okupirane Srbije) odnosno sremske (NDH) Jevreje. Ako se posmatra samo teritorija grada Beograda u Upravi grada Beograda (manja teritorija od Beogradskog regiona), Jevreji su predstavljali 3,31\% stanovništva. Definitivni rezultati popisa stanovništva od 31. marta 1931. godine, knjiga II, Prisutno stanovništvo prema veroispovesti, Beograd 1938, VIII-XII. Pošto popis stanovništva predviđen za 1941. godinu zbog izbijanja rata nije obavljen, prilikom posmatranja teritorijalnog rasporeda Jevreja u ratnom periodu treba u obzir uzeti migracije tokom prethodne decenije u okviru nacionalnog korpusa, prvenstveno ka Beogradu, kako Jevreja sa ove teritorije, tako i sunarodnika sa područja čitave Jugoslavije (najviše iz Makedonije i BiH), što je u izvesnoj meri narušilo prikazanu teritorijalnu strukturu. 
Tabela 2: Okupirana Srbija, Jevreji - gubici prema regionalnoj pripadnosti

\begin{tabular}{|c|c|c|c|c|c|c|c|}
\hline $\begin{array}{c}\text { Okupirana } \\
\text { Srbija - } \\
\text { Jevreji }\end{array}$ & Ukupno & $\begin{array}{c}\text { Beogradski } \\
\text { region }\end{array}$ & $\%$ & Banat & $\%$ & $\begin{array}{c}\text { Ostalih 8 } \\
\text { regiona OS }\end{array}$ & $\%$ \\
\hline Ukupno & 6.254 & 3.484 & 55,71 & 1.782 & 28,49 & 988 & 15,78 \\
\hline
\end{tabular}

AMŽG, Baza podataka „Žrtve rata 1941-1945“

Tabela 3: Okupirana Srbija, Jevreji - učešće u nacionalnom korpusu i učešće u gubicima prema regionalnoj pripadnosti u procentima

\begin{tabular}{|c|c|c|}
\hline $\begin{array}{c}\text { Okupirana Srbija }- \\
\text { Jevreji }\end{array}$ & $\begin{array}{c}\text { Učešće } \\
\text { u nacionalnom korpusu }\end{array}$ & $\begin{array}{c}\text { Učešće među } \\
\text { stradalima }\end{array}$ \\
\hline Beogradski region & 62,51 & 55,71 \\
\hline Banat & 29,39 & 28,49 \\
\hline Ostalih 8 regiona OS & 8,10 & 15,78 \\
\hline
\end{tabular}

Popis stanovništva 1931, AMŽG, Baza podataka „Žrtve rata 1941-1945“

Učešće u ukupnim gubicima Jevreja iz Beogradskog regiona, kao najveće zajednice, bilo je 1,12 puta manje od njihove zastupljenosti u jevrejskom nacionalnom korpusu, dok je zastupljenost u gubicima stradalih iz Banata bila jednaka. $\mathrm{S}$ druge strane, učešće u gubicima Jevreja stradalih iz ostalih osam regiona okupirane Srbije bilo je dvostruko veće od njihovog udela u nacionalnom korpusu. ${ }^{14}$

Jevreji iz okupirane Srbije, unapred određeni za potpuno uništenje, pretrpeli su gubitke među pripadnicima oba pola. Među stradalim Jevrejima bilo je neznatno više muškaraca (odnos u stradanju $1,13: 1$ ) ${ }^{15}$ Iako su oba pola uništavana u potpunosti, dinamika pretrpljenih gubitaka nije bila ista, kao što ni njihovo učešće u gubicima tokom rata nije bilo jednako.

Tabela 4: Okupirana Srbija, Jevreji - polna struktura prema godini stradanja

\begin{tabular}{|c|c|c|c|c|c|c|c|}
\hline $\begin{array}{c}\text { Jevreji okupira- } \\
\text { ne Srbije - pol }\end{array}$ & Ukupno & 1941. & $\%$ & 1942. & $\%$ & $\begin{array}{c}1943- \\
1945 .\end{array}$ & $\%$ \\
\hline Muškarci & 3.313 & 2.063 & 62,27 & 1.174 & 35,44 & 76 & 2,29 \\
\hline \% & 52,97 & 98,10 & $/ /$ & 29,30 & $/ /$ & 52,78 & $/ /$ \\
\hline Žene & 2.941 & 40 & 1,36 & 2.833 & 96,33 & 68 & 2,31 \\
\hline Ukupno & 47,02 & 1,90 & $/ /$ & 70,70 & $/ /$ & 47,22 & $/ /$ \\
\hline & 6.254 & 2.103 & 33,62 & 4.007 & 64,07 & 144 & 2,30 \\
\hline
\end{tabular}

AMŽG, Baza podataka „Žrtve rata 1941-1945“

${ }^{14}$ Tako velika razlika između broja Jevreja koji su živeli na ovoj teritoriji i broja stradalih može da bude posledica više činilaca. Moguće je da je stradanje Jevreja ovih oblasti bilo stvarno veće pošto ih je u malim sredinama bilo lakše pronaći, zatim da je deo Jevreja koji su popisani kao stradali ovog dela teritorije okupirane Srbije u stvari živeo u Beogradu, te da ih je trebalo brojati kao tamošnje gubitke ili da je obuhvatnost popisa u sredinama sa manjim jevrejskim zajednicama bila veća, pošto je bilo lakše popisati stradale nego u većim sredinama. Tokom procesa revizije popisa potrebno je rešiti ove probleme.

${ }^{15}$ Među preživelim Jevrejima Jugoslavije 1946. žene su činile 51,71\%, a muškarci 48,29\%. Ovaj odnos nije nužno primenjiv i na Jevreje sa teritorije okupirane Srbije, ali je indikativan za razumevanje pretrpljenih gubitaka. David Perera, „Neki statistički podaci o Jevrejima u Jugoslaviji u periodu od 1938. do 1965. godine“, Jevrejski almanah 1968-1970 (Beograd, 1971), 140. 
Nakon logorisanja gotovo svih muškaraca i manjeg dela žena u leto 1941. godine, pripadnici jevrejske zajednice muškog pola su od jeseni masovno stradali u masovnim streljanjima širom Srbije kao odmazda za stradanje Nemaca poginulih u borbi sa ustanicima ili kao mera zastrašivanja stanovništva u cilju odvraćanja od pridruživanja ustanicima. Stoga je više od tri petine Jevreja muškaraca stradalo u 1941. godini. Nastavak uništenja jevrejske zajednice u okupiranoj Srbiji prouzrokovao je da je još trećina pripadnika muškog pola izgubila život u 1942. godini, dok ih je gotovo zanemarljiv deo stradao u periodu do kraja rata. U prvoj godini rata ubijeno je 1,76 puta više muškaraca nego u narednoj, ali je, s obzirom na duplo duži period njihovog uništenja u 1942. godini nego u prethodnoj, njihovo stradanje u 1941. bilo realno 3,51 puta veće, dok je gubitak u 1942. godini bio realno 36,06 puta veći nego u potonjem periodu. Masovno uništenje Jevrejki sprovedeno je u 1942. godini, tako da su zanemarljivi delovi stradali u prethodnom i potonjem periodu rata, čime je gubitak žena u 1942. godini bio realno 35,41 puta veći nego u prethodnoj godini i 96,73 puta veći od pretrpljenog gubitka u poslednje tri godine rata. U prvoj godini rata udeo stradalih muškaraca je bio 45,79 puta veći od udela stradalih žena, dok je u 1942. udeo stradalih Jevrejki bio 2,72 puta veći od udela stradalih muškaraca, da bi se kod oba pola udeo u gubicima u poslednje tri godine rata izjednačio.

Dinamika stradanja polova jevrejske zajednice u okupiranoj Srbiji odredila je u bitnoj meri i njihovo učešće u gubicima tokom rata. Muškarci su predstavljali gotovo jedine stradale u prvoj godini rata, sa učešćem u gubicima koje je bilo 51,63 puta veće od učešće žena. Masovno stradanje Jevrejki u 1942. godini donelo je promenu u zastupljenosti polova u gubicima, tako da su žene predstavljale više od dve trećine gubitaka, 2,41 puta veće od učešća muškaraca. U odnosu na prethodnu godinu učešće muškaraca u gubicima Jevreja bilo je smanjeno 3,38 puta, dok je učešće žena u gubicima bilo 37,21 puta veće. U poslednje tri godine rata, kada je proces holokausta bio gotovo okončan, polovi su imali izjednačeno učešće u gubicima, koje je odgovaralo njihovoj zastupljenosti u ukupnim gubicima.

Mesta stradanja Jevreja iz okupirane Srbije bila su uglavnom uslovljena situacijom na toj teritoriji, a što je opet bilo u tesnoj vezi i sa vremenom njihovog stradanja. Matična teritorija je predstavlja primarno mesto stradanja pošto su gotovo svi pripadnici jevrejske zajednice izgubili živote na teritoriji okupirane Srbije, uz jako male delove koji su stradali u ostalom delu Jugoslavije ili u inostranstvu.

Tabela 5: okupirana Srbija, Jevreji - mesta stradanja

\begin{tabular}{|c|c|c|c|c|c|c|c|c|c|}
\hline $\begin{array}{c}\text { Okupirana } \\
\text { Srbija }\end{array}$ & Ukupno & $\begin{array}{c}\text { U okupira- } \\
\text { noj Srbiji }\end{array}$ & $\%$ & $\begin{array}{c}\text { U } \\
\text { Jugoslaviji }\end{array}$ & $\%$ & $\begin{array}{c}\text { U } \\
\text { inostranstvu }\end{array}$ & $\%$ & Nepoznato & $\%$ \\
\hline Ukupno & 6.254 & 6.027 & 96,37 & 113 & 1,81 & 106 & 1,69 & 8 & 0,13 \\
\hline
\end{tabular}

Kao i u većini drugih zemalja Evrope stradanje Jevreja je bilo povezano sa koncentracionim logorima ili sa neposredno izvođenim egzekucijama. Najveći deo 
jevrejske zajednice okupirane Srbije bio je povezan sa stradanjem neposredno nakon boravka u nekom logoru ili sa stradanjem u nekom od logora, dok je samo mali deo njih (pedeseti deo) živote izgubio u drugim okolnostima, najčešće streljanjem odmah nakon hapšenja.

Tabela 6: Okupirana Srbija, Jevreji - okolnosti stradanja

\begin{tabular}{|c|c|c|c|c|c|}
\hline $\begin{array}{c}\text { Okupirana } \\
\text { Srbija }\end{array}$ & Ukupno & U logoru & $\%$ & $\begin{array}{c}\text { Ostale } \\
\text { okolnosti }\end{array}$ & $\%$ \\
\hline Ukupno & 6.254 & 6.138 & 98,14 & 116 & 1,84 \\
\hline
\end{tabular}

AMŽG, Baza podataka „Žrtve rata 1941-1945“

Tabela 7: Okupirana Srbija, Jevreji - stradali u logorima prema mestu stradanja

\begin{tabular}{|c|c|c|c|c|c|c|c|}
\hline $\begin{array}{c}\text { Okupirana } \\
\text { Srbija }\end{array}$ & Ukupno & $\begin{array}{c}\text { Topovske } \\
\text { šupe }\end{array}$ & $\%$ & Zemun & $\%$ & $\begin{array}{c}\text { Ostali } \\
\text { logori }\end{array}$ & $\%$ \\
\hline Ukupno & 6.138 & 1.857 & 30,25 & 3.551 & 57,85 & 730 & 11,89 \\
\hline
\end{tabular}

AMŽG, Baza podataka „Žrtve rata 1941-1945“

Jevrejska zajednica iz okupirane Srbije stradala je u više logora koji su se nalazili bilo u okviru okupirane teritorije, bilo van nje, što na prostoru podeljene Jugoslavije ili u inostranstvu. Centralno mesto u sprovođenju holokausta u okupiranoj Srbiji predstavljali su logori Topovske šupe (Jevrejski logor, Jevrejski prolazni logor u Beogradu) i Jevrejski logor Zemun (Judenlager Semlin) ${ }^{16} \mathrm{u}$ kojima je život izgubilo $88,11 \%$ Jevreja stradalih u logorima. Osmina od ukupnog broja stradalih u logorima izgubila je živote u nekom od drugih logora. ${ }^{17}$

Logor koji su Nemci organizovali u Topovskim šupama na Autokomandi poslužio je od avgusta 1941. za utamničenje Jevreja, ali i dela Roma. Logor je tokom tri meseca postojanja prvenstveno služio kao rezervoar talaca za streljanja zbog nemačkih gubitaka pretrpljenih u borbama sa ustanicima u Srbiji. ${ }^{18}$

Tabela 8: Logor Topovske šupe - teritorijalna pripadnost

\begin{tabular}{|c|c|c|c|c|c|}
\hline $\begin{array}{c}\text { Topovske } \\
\text { špe }\end{array}$ & Ukupno & $\begin{array}{c}\text { Okupirana } \\
\text { Srbija }\end{array}$ & $\%$ & $\begin{array}{c}\text { Ostale } \\
\text { teritorije }\end{array}$ & $\%$ \\
\hline Ukupno & 1.942 & 1.903 & 97,99 & 39 & 2,01 \\
\hline
\end{tabular}

AMŽG, Baza podataka „Žrtve rata 1941-1945“

Tabela 9: Logor Topovske šupe - teritorijalna pripadnost stradalih iz okupirane Srbije

\begin{tabular}{|c|c|c|c|c|c|c|c|}
\hline $\begin{array}{c}\text { Okupirana Srbija } \\
\text { Topovske šupe }\end{array}$ & Ukupno & $\begin{array}{c}\text { Beogradski } \\
\text { region }\end{array}$ & $\%$ & Banat & $\%$ & $\begin{array}{c}\text { Ostalih } \\
8 \text { regiona }\end{array}$ & $\%$ \\
\hline Ukupno & 1.903 & 1.128 & 59,27 & 695 & 36,52 & 80 & 4,20 \\
\hline
\end{tabular}

AMŽG, Baza podataka ,Žrtve rata 1941-1945“

\footnotetext{
${ }^{16}$ M. Koljanin, Nemački logor na Beogradskom sajmištu, 34, 64.

${ }^{17}$ Među ostalim logorima izdvajaju se logori na teritoriji okupirane Srbije u Nišu (Crveni krst Anhaltelager Nisch) i Beogradu (Banjica - Anhaltelager Dedinje), Jasenovac u NDH kao logor na teritoriji ostalog dela Jugoslavije i Aušvic (Auschwitz) i Treblinka (od logora u inostranstvu).

18 Opširnije o logoru, vremenu, razlozima i opštem kontekstu njegovog nastanka, arhitekturi videti u: M. Koljanin, Nemački logor na Beogradskom sajmištu, 26-42; Nenad Žarković, „Prolazni logor Topovske Šupe“, Nasleđe, br. 10, (2009), 103-112.
} 
Oformljen za zatočenike sa teritorije okupirane Srbije, logor je primao zatvorenike koji su prikupljani sa te teritorije. Među logorašima se našao i mali broj zatočenika sa drugih teritorija, koji su se u momentu hapšenja iz različitih razloga zatekli na okupiranoj teritoriji. Oni su predstavljali pedeseti deo žrtava logora.

Zatočenici logora iz okupirane Srbije nisu u jednakom broju dovođeni u logor. Tri petine svih gubitaka pretrpljenih u logoru na Autokomandi poticalo je iz Beogradskog regiona, više od trećine iz Banata, dok je svega dvadeset četvrti deo poticao iz ostalih delova okupirane teritorije. Neravnomerno dovođenje zatočenika u logor bila je, s jedne strane, posledica njegove prvobitne namene, logora za Jevreje, čija je zastupljenost u populaciji okupirane Srbije odredila i teritorijalnu pripadnost žrtava logora, dok je, s druge strane, na teritorijalnu pripadnost zatočenika uticalo i postojanje drugih koncentracionih logora.

Tabela 10: Logor Topovske šupe - nacionalna struktura stradalih iz okupirane Srbije

\begin{tabular}{|c|c|c|c|c|c|}
\hline $\begin{array}{c}\text { OS, logor } \\
\text { Topovske šupe }\end{array}$ & Ukupno & Jevreji & $\%$ & Romi & $\%$ \\
\hline Ukupno & 1.903 & 1.857 & 97,58 & 46 & 2,42 \\
\hline
\end{tabular}

AMŽG, Baza podataka „Žrtve rata 1941-1945“

Nacionalna struktura stradalih u logoru pokazuje da u njemu nisu stradali isključivo Jevreji. Pored njih, koji su predstavljali najveći deo stradalih, u logor su dovođeni i Romi, uglavnom iz Beograda. ${ }^{19}$ Streljanjem ubijeni Jevreji koji su prethodno bili logorisani u Topovskim šupama predstavljali su $88,30 \%$ stradalih sunarodnika 1941. godine.

U logor Topovske šupe dovođeni su muškarci Jevreji sa teritorije čitave okupirane Srbije. Tri petine stradalih u logoru predstavljali su Jevreji iz Beogradskog regiona, nešto više od trećine iz Banata, dok su muškarci Jevreji iz ostalog dela okupirane Srbije činili dvadeset peti deo gubitaka. Zastupljenost Jevreja u logoru zavisila je od njihove zastupljenosti u stanovništvu u pojedinim delovima okupirane teritorije, a i od postojanja drugih logora u njoj. Time ni učešće Jevreja iz različitih regiona u gubicima u logoru Topovske šupe nije uvek bilo u skladu sa njihovom udelom u nacionalnom korpusu.

Tabela 11: Logor Topovske šupe, Jevreji-teritorijalna pripadnost stradalih iz okupirane Srbije

\begin{tabular}{|c|c|c|c|c|c|c|c|}
\hline $\begin{array}{c}\text { Jevreji OS, } \\
\text { logor Topov- } \\
\text { ske šupe }\end{array}$ & Ukupno & $\begin{array}{c}\text { Beogradski } \\
\text { region }\end{array}$ & $\%$ & Banat & $\%$ & $\begin{array}{c}\text { Ostalih } 8 \\
\text { regiona }\end{array}$ & $\%$ \\
\hline Ukupno & 1.857 & 1.088 & 58,59 & 693 & 37,32 & 76 & 4,09 \\
\hline
\end{tabular}

AMŽG, Baza podataka „Žrtve rata 1941-1945“

${ }^{19}$ Popisom „Žrtve rata 1941-1945” iz 1964. godine Romi nisu tretirani kao posebna nacionalna grupa već su, u slučaju posmatrane teritorije, uglavnom navođeni kao Srbi, a u manjem broju kao Muslimani. Jedan od ciljeva revizije popisa koju sprovodi Muzej žrtava genocida jeste otklanjanje te greške identifikovanjem stradalih pripadnika romske zajednice. Opširnije o stradanju Roma sa teritorije okupirane Srbije videti u: Milovan Pisari, Stradanje Roma u Srbiji za vreme holokausta (Beograd: Forum za primenjenu istoriju, 2014). 
Sa dve petine gubitaka u logoru, stradanje Jevreja iz Banata bilo je realno 1,27 puta veće od njihove zastupljenosti u nacionalnom korpusu. Čineći tri petina gubitaka, pripadnici jevrejske zajednice iz Beograda bili su u skladu sa svojom zastupljenošću u nacionalnom korpusu (stvarno 1,07 puta manji), dok je učešće Jevreja iz ostalog dela okupirane Srbije bilo dvostruko manje od njihovog udela $u$ nacionalnom korpusu. Time je gubitak koji su Jevreji iz Banata pretrpeli u logoru Topovske šupe bio 1,59 puta manji od gubitaka Jevreja iz Beograda, a 9,12 puta veći od gubitaka sunarodnika iz ostalog dela okupirane teritorije, ali je, s obzirom na zastupljenost Jevreja sa različitih delova okupirane teritorije u nacionalnom korpusu, njihov gubitak bio realno 1,36 odnosno 2,51 puta veći. $^{20}$

Težnja Nemaca da u početnoj fazi holokausta unište najvitalniji deo jevrejske zajednice u okupiranoj Srbiji bitno je uticala na starosnu strukturu zatočenika logora Topovske šupe. U logoru stradali muškarci Jevreji bili su uzrasta između 15 i 60 godina. Po četvrtinu pretrpljenih gubitaka u logoru predstavljali su muškarci dobi od 25 do 34 i 35 do 44 godina, po petinu uzrasti 15 do 24 i 45 do 54 godina, dok su devetinu činili Jevreji starosti između 55 i 64 godina. ${ }^{21}$ Starosna struktura Jevreja stradalih u logoru iz različitih delova okupirane Srbije nije bila jednaka. ${ }^{22}$

Tabela 12: Logor Topovske šupe, Jevreji - starosna struktura prema teritorijalnoj pripadnosti

\begin{tabular}{|c|c|c|c|c|c|c|c|}
\hline $\begin{array}{c}\text { Jevreji OS, logor } \\
\text { Topovske šupe } \\
- \text { uzrast }\end{array}$ & Ukupno & $\begin{array}{c}\text { Beogradski } \\
\text { region }\end{array}$ & $\%$ & Banat & $\%$ & $\begin{array}{c}\text { Ostalih } \\
8 \text { regi- } \\
\text { ona }\end{array}$ & $\%$ \\
\hline do 14 & - & - & - & - & - & - & - \\
\hline$\%$ & - & - & $/ /$ & - & $/ /$ & - & $/ /$ \\
\hline 15 do 24 & 308 & 201 & 65,26 & 101 & 32,79 & 5 & 1,62 \\
\hline$\%$ & 18,10 & 19,22 & $/ /$ & 16,50 & $/ /$ & 11,36 & $/ /$ \\
\hline 25 do 34 & 392 & 270 & 68,88 & 106 & 27,04 & 16 & 4,08 \\
\hline$\%$ & 23,03 & 25,81 & $/ /$ & 17,32 & $/ /$ & 36,36 & $/ /$ \\
\hline 35 do 44 & 443 & 269 & 60,72 & 163 & 36,79 & 12 & 2,71 \\
\hline$\%$ & 26,23 & 25,72 & $/ /$ & 26,63 & $/ /$ & 27,27 & $/ /$ \\
\hline 45 do 54 & 361 & 208 & 57,62 & 148 & 41,00 & 5 & 1,38 \\
\hline$\%$ & 21,21 & 19,88 & $/ /$ & 24,18 & $/ /$ & 11,36 & $/ /$ \\
\hline 55 do 64 & 198 & 98 & 49,49 & 94 & 47,47 & 6 & 3,03 \\
\hline$\%$ & 11,63 & 9,37 & $/ /$ & 15,36 & $/ /$ & 13,64 & $/ /$ \\
\hline 65 i više & - & - & - & - & - & - & - \\
\hline
\end{tabular}

${ }^{20}$ Realan gubitak beogradskih Jevreja u logoru Topovske šupe bio je 1,85 puta veći od pretrpljenog gubitka sunarodnika iz ostalih osam regiona okupirane Srbije (bez Banata).

${ }^{21}$ Među stradalima uzrasta od 55 do 64 godine $75,75 \%$ činili su muškarci uzrasta 55-60 godina.

22 Starosna struktura stradalih u logoru Topovske šupe iz različitih delova okupirane Srbije nije bila poznata u jednakoj meri, tako da je najbolje utvrđena kod Jevreja iz Beogradskog regiona, nešto lošije kod Jevreja iz Banata, dok je najlošije utvrđena kod njihovih sunarodnika iz ostalog dela okupirane Srbije, kod kojih je nepoznata za dve petine gubitaka. 
Logori Topovske šupe i Sajmište kao centralna mesta holokausta...

\begin{tabular}{|c|c|c|c|c|c|c|c|}
\hline$\%$ & - & - & $/ /$ & - & $/ /$ & - & $/ /$ \\
\hline ukupno poznato & 1.702 & 1.046 & 61,46 & 612 & 35,96 & 44 & 2,58 \\
\hline \hline nepoznat uzrast & 155 & 42 & 27,10 & 81 & 52,26 & 32 & 20,64 \\
\hline$\%$ & 8,35 & 3,86 & $/ /$ & 11,69 & $/ /$ & 42,10 & $/ /$ \\
\hline Ukupno AMŽG, Baza podataka ,Žrtve rata 1941-1945“ & 1.088 & 58,59 & 693 & 37,32 & 76 & 4,09 \\
\hline
\end{tabular}

Zastupljenost starosnih uzrasta u gubicima Jevreja iz različitih delova okupirane Srbije stradalih u logoru Topovske šupe nije bila jednaka. Gotovo polovinu stradalih iz Beogradskog regiona $(45,03 \%)$, kao i iz ostalog dela okupirane teritorije $(47,72 \%)$ činili su muškarci uzrasta od 15 do 34 godina starosti, s time što su pripadnici starije uzrasne grupe kod stradalih Jevreja iz Beogradskog regiona bili 1,34 puta zastupljeniji u gubicima, dok su među stradalima iz ostalog dela okupirane Srbije imali 3,20 puta veće učešće. S druge strane, među banatskim Jevrejima stradali ovih dobi predstavljali su trećinu pretrpljenih gubitaka $(33,82 \%)$ u logoru u Topovskim šupama, sa izjednačenim učešćem obe uzrasne grupe. Zastupljenost mlađih uzrasta u gubicima Jevreja iz Beogradskog regiona i ostalih 8 regiona okupirane Srbije bila je 1,33 odnosno 1,41 puta veća nego među Jevrejima iz Banata. Sa dve petine stradalih starosne dobi između 45 i 64 godina, žrtve logora iz Banata $(39,54 \%)$ bile su prosečno dosta starije od svojih sunarodnika iz Beograda $(29,25 \%)$ i ostalog dela okupirane teritorije $(25,00 \%)$, sa 1,35 odnosno 1,58 puta većim učešćem ovih uzrasta u gubicima.

Beogradski Jevreji koji su činili tri petina gubitaka predstavljali su najveći deo stradalih u svim uzrasnim grupama, ali sa nejednakim udelom, tako da su činili po dve trećine stradalih uzrasta 15 do 24 i 25 do 34 godina, ali i manje od polovine gubitaka dobi 55 do 64 godina. S druge strane, stradali Jevreji iz Banata su imali veće udele među stradalima starijih dobi, činivši polovinu stradalih starosne grupe 55 do 64 godina, dok su njihovi sunarodnici iz ostalog dela okupirane teritorije imali različite udele, značajniji u gubicima uzrasta 25 do 34 godina starosti i manji u dobi 45 do 54 godina.

Težnja Nemaca da u prvoj fazi sprovođenja holokausta na teritoriji okupirane Srbije uništi muškarce određene dobi uslovila je profesionalnu strukturu jevrejskih žrtava logora Topovske šupe. Više od dve petine stradalih predstavljali su privrednici, uz četvrtinu službenika i stručnjaka različitih profila, praćenih sa osminom odnosno devetinom gubitaka koje su činili učenici i studenti ${ }^{23}$ odnosno radnici. Jevreji iz različitih delova okupirane teritorije stradali u logoru Topovske šupe nisu imali jednaku profesionalnu strukturu ${ }^{24} \mathrm{i}$ ona je bila uslovljena kako njihovom predratnom profesionalnom strukturom, tako i brojem Jevreja poslatih u logor.

\footnotetext{
${ }^{23}$ Studenti (90) su među stradalim učenicima i studentima predstavljali dve petine gubitaka $(42,65 \%)$.

${ }^{24}$ Profesionalna struktura pripadnika jevrejske zajednice iz različitih delova okupirane Srbije stradalih u logoru Topovske šupe nije bila poznata u jednakoj meri. Najlošije je utvrđena kod Jevreja iz Banata, znatno bolje kod Jevreja iz Beogradskog regiona, dok je najbolje utvrđena kod njihovih sunarodnika iz ostalog dela okupirane Srbije, kod kojih je u potpunosti poznata.
} 
Tabela 13: Logor Topovske šupe, Jevreji-profesionalna struktura prema teritorijalnoj pripadnosti

\begin{tabular}{|c|c|c|c|c|c|c|c|}
\hline $\begin{array}{l}\text { Jevreji OS, } \\
\text { logor Topovske } \\
\text { šupe -prof. }\end{array}$ & Ukupno & $\begin{array}{c}\text { Beogradski } \\
\text { region }\end{array}$ & $\%$ & Banat & $\%$ & $\begin{array}{l}\text { Ostalih } 8 \\
\text { regiona }\end{array}$ & $\%$ \\
\hline poljoprivrednici & 9 & - & - & 8 & 88,89 & 1 & 11,11 \\
\hline$\%$ & 0,53 & - & $/ /$ & 1,37 & $/ /$ & 1,31 & $/ /$ \\
\hline privrednici & 733 & 400 & 54,57 & 293 & 39,97 & 40 & 5,46 \\
\hline$\%$ & 43,45 & 38,99 & $/ /$ & 50,08 & $/ /$ & 52,63 & $/ /$ \\
\hline radnici & 187 & 142 & 75,93 & 40 & 21,39 & 5 & 2,67 \\
\hline$\%$ & 11,08 & 13,84 & $/ /$ & 6,84 & $/ /$ & 6,58 & // \\
\hline vojska, policija & 1 & 1 & 100,0 & - & - & - & - \\
\hline$\%$ & 0,06 & 0,10 & $/ /$ & - & // & - & // \\
\hline službenici, stuč. & 436 & 278 & 63,76 & 143 & 32,80 & 15 & 3,44 \\
\hline$\%$ & 25,84 & 27,09 & $/ /$ & 24,44 & // & 19,74 & $/ /$ \\
\hline slob. profesija & 58 & 34 & 58,62 & 22 & 37,93 & 2 & 3,45 \\
\hline$\%$ & 3,44 & 3,31 & $/ /$ & 3,76 & // & 2,63 & // \\
\hline izdržavana lica & 29 & 15 & 51,72 & 7 & 24,14 & 7 & 24,14 \\
\hline$\%$ & 1,72 & 1,46 & $/ /$ & 1,20 & $/ /$ & 9,21 & $/ /$ \\
\hline đaci i studenti & 211 & 144 & 68,25 & 61 & 28,91 & 6 & 2,84 \\
\hline$\%$ & 12,51 & 14,03 & $/ /$ & 10,43 & // & 7,89 & // \\
\hline ostala zanimanja & 9 & 5 & 55,56 & 4 & 44,44 & - & - \\
\hline$\%$ & 0,53 & 0,49 & $/ /$ & 0,68 & // & - & // \\
\hline lični prihodi & 10 & 5 & 50,00 & 5 & 50,00 & - & - \\
\hline$\%$ & 0,59 & 0,49 & $/ /$ & 0,85 & // & -- & $/ /$ \\
\hline nezaposleni & 4 & 2 & 50,00 & 2 & 50,00 & -- & -- \\
\hline$\%$ & 0,24 & 0,19 & $/ /$ & 0,34 & // & -- & $/ /$ \\
\hline ukupno poznata & 1.687 & 1.026 & 60,82 & 585 & 34,68 & 76 & 4,50 \\
\hline nepoznata zan. & 170 & 62 & 36,47 & 108 & 63,53 & -- & -- \\
\hline$\%$ & 9,15 & 5,70 & // & 15,58 & // & -- & // \\
\hline Ukupno & 1.857 & 1.088 & 58,59 & 693 & 37,32 & 76 & 4,09 \\
\hline
\end{tabular}

AMŽG, Baza podataka ,Žrtve rata 1941-1945“

Učešće profesija u gubicima Jevreja iz različitih delova okupirane Srbije stradalih u logoru Topovske šupe nije bila jednako. Privrednici su predstavljali najbrojniju profesionalnu grupu među stradalim Jevrejima iz sva tri dela okupirane teritorije, tako da su činili dve petine stradalih iz Beograda i po polovinu gubitaka iz Banata i ostalog dela okupirane Srbije. Zastupljenost radnika u gubicima beogradskih Jevreja, gde su predstavljali sedminu gubitaka, bila je dvostruko veća nego među sunarodnicima iz ostala dva dela okupirane teritorije. Trećinu odnosno više od četvrtine gubitaka Jevreja iz Beogradskog regiona i Banata stradalih u logoru u Topovskim šupama predstavljali su službenici i stručnjaci različitih profila, te pripadnici slobodnih profesija (30,40 odnosno 
$28,20 \%$ ), što je bilo 1,36 odnosno 1,21 puta veće učešće nego među sunarodnicima iz ostalih 8 regiona okupirane teritorije $(22,37 \%)$. Studenti i mahom srednjoškolski učenici predstavljali su sedminu gubitaka Jevreja Beogradskog regiona stradalih u logoru Topovske šupe, što je bila 1,34 odnosno 1,78 puta veća zastupljenost u gubicima nego među banatskim i Jevrejima iz ostalih osam regiona okupirane Srbije. ${ }^{25}$ Zanemarljivo učešće u gubicima među Jevrejima iz Banata i ostalog dela okupirane Srbije predstavljali su poljoprivrednici, kojih nije bilo među stradalim beogradskim Jevrejima.

Beogradski Jevreji, koji su činili tri petine gubitaka, predstavljali su najveći deo stradalih u gotovo svim profesionalnim grupama, ali sa nejednakim udelom, tako da su činili tri četvrtine stradalih radnika i dve trećine učenika i studena$\mathrm{ta}^{26}{ }^{26}$ ali i polovinu gubitaka privrednika. S druge strane, stradali Jevreji iz Banata su imali veće udele među stradalim privrednicima i pripadnicima slobodnih profesija, a činili su devet desetina stradalih poljoprivrednika, ali su imali i dosta manji udeo među stradalim radnicima. Njihovi sunarodnici iz ostalog dela okupirane teritorije imali su višestruko veće udele među stradalim izdržavanim licima i poljoprivrednicima, a manje u svim ostalim profesionalnim grupama.

Radi efikasnijeg sprovođenja „konačnog rešenja jevrejskog pitanja“ $u$ okupiranoj Srbiji Nemci su odlučili da predviđeni koncentracioni logor na Beogradskom sajmištu pretvore u logor za Jevreje, Judenlager Semlin. Prvi logoraši su u njega dovedeni početkom decembra 1941.

Tabela 14: Logor Zemun Sajmište - teritorijalna pripadnost

\begin{tabular}{|c|c|c|c|c|c|}
\hline $\begin{array}{c}\text { Zemun } \\
\text { Sajmište }\end{array}$ & Ukupno & $\begin{array}{c}\text { Okupirana } \\
\text { Srbija }\end{array}$ & $\%$ & $\begin{array}{c}\text { Ostale } \\
\text { teritorije }\end{array}$ & $\%$ \\
\hline Ukupno & 3.616 & 3.604 & 99,67 & 8 & 0,33 \\
\hline
\end{tabular}

AMŽG, Baza podataka „Žrtve rata 1941-1945“

Oformljen za zatočenike sa teritorije okupirane Srbije, logor je primao zatvorenike koji su prikupljani sa te teritorije. Među logorašima se našao i mali broj zatočenika iz drugih delova Jugoslavije, koji su se u momentu hapšenja iz različitih razloga zatekli na okupiranoj teritoriji. Oni su predstavljali zanemarljiv deo žrtava logora. Takođe, logor je poslužio za uništenje preostalih Jevreja emigranata koji su se u početnoj fazi rata zatekli na okupiranoj teritoriji, a do tada su se nalazili u logoru u Šapcu. ${ }^{27}$

U Judenlager su prvo dovedeni Jevreji iz Beograda, kako domaći, tako i u njemu internirani Jevreji iz Banata, a zatim i njihovi sunarodnici iz ostalog dela okupirane Srbije. Najveće grupe pristiglih krajem zime i u rano proleće 1942. godi-

${ }^{25}$ Studenti su među stradalim učenicima i studentima iz Beogradskog regiona predstavljali $48,97 \%$ gubitaka, iz Banata 47,54\%, a među stradalima iz ostalih 8 regiona 33,33\%.

${ }^{26}$ Među stradalim studentima u Topovskim šupama $65,55 \%$ poticalo je iz Beogradskog regiona (59), 32,22\% iz Banata (29) i 2,22\% iz ostalih 8 regiona okupirane teritorije (2).

${ }^{27}$ Opširnije o sudbini jevrejskih emigranata u okupiranoj Srbiji videti: M. Koljanin, „Poslednje putovanje Kladovskog transporta“, u: Kladovo transport / The Kladovo transport, Zbornik radova, $65-101$. 
ne bili su internirci iz logora u Nišu, zatim Jevreji iz Novog Pazara i sa dela Kosova i Metohije. Pored prve grupe Jevreja u logor je dopremljena i grupa Roma.

Tabela 15: Logor Zemun Sajmište - teritorijalna pripadnost stradalih iz okupirane Srbije

\begin{tabular}{|c|c|c|c|c|c|c|c|}
\hline $\begin{array}{c}\text { Zemun } \\
\text { Sajmište }\end{array}$ & Ukupno & $\begin{array}{c}\text { Beogradski } \\
\text { region }\end{array}$ & $\%$ & Banat & $\%$ & $\begin{array}{c}\text { Ostalih } 8 \\
\text { regiona }\end{array}$ & $\%$ \\
\hline Ukupno & 3.604 & 2.070 & 57,44 & 1.054 & 29,24 & 480 & 13,32 \\
\hline
\end{tabular}

Tabela 16: Logor Zemun Sajmište - nacionalna struktura stradalih iz okupirane Srbije

\begin{tabular}{|c|c|c|c|c|c|}
\hline $\begin{array}{c}\text { Zemun } \\
\text { Sajmište }\end{array}$ & Ukupno & Jevreji & $\%$ & Romi & $\%$ \\
\hline Ukupno & 3.604 & 3.551 & 98,53 & 53 & 1,47 \\
\hline
\end{tabular}

AMŽG, Baza podataka „Žrtve rata 1941-1945“

Namena logora da posluži za konačno rešenje jevrejskog pitanja u okupiranoj Srbiji uslovila je i nacionalnu strukturu njegovih žrtava. Gotovo sve stradale u logoru činili su pripadnici jevrejske zajednice. ${ }^{28}$ Najveći deo utamničenih Roma u logoru oslobođen je do kraja marta $1942,{ }^{29}$ tako da su oni predstavljali tek šezdeset osmi deo gubitaka pretrpljenih u Judenlageru. ${ }^{30}$

Kulminacija holokausta na teritoriji okupirane Srbije 1942. godine pogodila je Jevreje iz svih njenih delova. Tri petina stradalih u logoru na Sajmištu predstavljali su Jevreji iz Beograda, nešto manje od trećine sunarodnici iz Banata, a nešto više od osmine Jevreji iz ostalog dela okupirane Srbije. Pretrpljeni gubici u tek nešto više od pola meseca postojanja logora u 1941. godini bili su minimalni, tako da se sveukupno stradanje u Judenlageru Semlin vezuje za 1942. godinu.

Tabela 17: Logor Zemun Sajmište, Jevreji - teritorijalna pripadnost stradalih iz okupirane Srbije prema godini stradanja

\begin{tabular}{|c|c|c|c|c|c|}
\hline $\begin{array}{c}\text { Jevreji OS - } \\
\text { Zemun Sajmište }\end{array}$ & Ukupno & 1941 & $\%$ & 1942 & $\%$ \\
\hline Beogradski & 2.026 & 5 & 0,25 & 2.021 & 99,75 \\
\hline$\%$ & 57,05 & 62,50 & $/ /$ & 57,04 & $/ /$ \\
\hline Banat & 1.054 & 1 & 0,09 & 1.053 & 99,91 \\
\hline$\%$ & 29,68 & 12,50 & $/ /$ & 29,72 & $/ /$ \\
\hline 8 regiona & 471 & 2 & 0,42 & 469 & 99,58 \\
\hline$\%$ & 13,26 & 25,00 & $/ /$ & 13,24 & $/ /$ \\
\hline Ukupno & 3.551 & 8 & 0,22 & 3.543 & 99,78 \\
\hline
\end{tabular}

AMŽG, Baza podataka „Žrtve rata 1941-1945“

\footnotetext{
${ }^{28}$ U broj stradalih u logoru za Jevreje na Beogradskom sajmištu uračunate su i žrtve iz Jevrejske bolnice u Beogradu, kako bolesnici, tako i osoblje bolnice i članovi njihovih porodica koje su se tamo nalazili.

${ }^{29}$ Opširnije o sudbini Roma u logoru na Sajmištu videti u: M. Koljanin, Nemački logor na Beogradskom sajmištu, 98-106.

30 Od stradalih Roma u logoru na Beogradskom sajmištu 83,02\% poticalo je iz Beogradskog regiona, a 16,98\% iz 8 regiona okupirane teritorije, dok među njima nije bilo Roma iz Banata.
} 
Stradanje u logoru nije bilo u skladu sa zastupljenošću u okviru nacionalnog korpusa Jevreja iz različitih delova teritorije. Učešće u gubicima logora Sajmište Jevreja iz Beogradskog regiona, kao najveće zajednice, bilo je 1,09 puta manje od njihove zastupljenosti u jevrejskom nacionalnom korpusu, dok je zastupljenost u gubicima stradalih iz Banata bila jednaka. S druge strane, učešće u gubicima u logoru Jevreja iz ostalih osam regiona okupirane Srbije bilo je 1,64 puta veće od njihovog udela u nacionalnom korpusu. Gubitak koji su Jevreji iz Beograda pretrpeli u logoru je dvostruko veći (1,92 puta) od gubitaka Jevreja iz Banata, a 4,30 puta veći od gubitaka sunarodnika iz ostalog dela okupirane teritorije, ali je, s obzirom na zastupljenost Jevreja iz različitih delova okupirane Srbije u nacionalnom korpusu, gubitak Jevreja iz osam regiona unutrašnjosti okupirane teritorije bio realno 1,79 odnosno 1,62 puta veći od gubitka sunarodnika iz Beograda i Banata.

Vreme formiranja Judenlagera Semlin, nakon okončanja početne faze holokausta u okupiranoj Srbiji, bitno je uticalo na polnu strukturu zatočenih logoraša. Iako su u njemu bili logorisani Jevreji oba pola, četiri petine žrtava u logoru činile su osobe ženskog pola. Muškarci koji su 1942. godine stradali u Jevrejskom logoru Zemun predstavljali su $65,50 \%$ gubitaka ovog pola te godine, dok su u logoru stradale Jevrejke činile $97,92 \%$ stradalih žena te godine. Stradali logoraši oba pola poticali su iz svih delova okupirane Srbije.

Tabela 18: Logor Zemun Sajmište, Jevreji - polna struktura prema godini stradanja

\begin{tabular}{|c|c|c|c|c|c|}
\hline $\begin{array}{c}\text { Jevreji OS, logor } \\
\text { Zemun - pol }\end{array}$ & Ukupno & 1941 & $\%$ & 1942 & $\%$ \\
\hline Muškarci & 777 & 8 & 1,03 & 769 & 98,97 \\
\hline$\%$ & 21,88 & 100,0 & $/ /$ & 21,71 & $/ /$ \\
\hline Žene & 2.774 & - & - & 2.774 & 100,0 \\
\hline$\%$ & 78,12 & - & $/ /$ & 78,29 & $/ /$ \\
\hline Ukupno & 3.551 & $8^{31}$ & 0,39 & 3.543 & 99,61 \\
\hline
\end{tabular}

AMŽG, Baza podataka „Žrtve rata 1941-1945“

Tabela 19: Logor Zemun Sajmište, Jevreji - polna struktura prema teritorijalnoj pripadnosti

\begin{tabular}{|c|c|c|c|c|c|c|c|}
\hline $\begin{array}{c}\text { Jevreji OS, logor } \\
\text { Zemun - pol }\end{array}$ & Ukupno & $\begin{array}{c}\text { Beogradski } \\
\text { region }\end{array}$ & $\%$ & Banat & $\%$ & $\begin{array}{c}\text { Ostalih } 8 \\
\text { regiona }\end{array}$ & $\%$ \\
\hline Muškarci & 777 & 466 & 59,97 & 226 & 29,09 & 85 & 10,94 \\
\hline$\%$ & 21,88 & 23,00 & $/ /$ & 21,44 & $/ /$ & 18,05 & $/ /$ \\
\hline Žene & 2.774 & 1.560 & 56,24 & 828 & 29,85 & 386 & 13,91 \\
\hline$\%$ & 78,12 & 77,00 & $/ /$ & 78,56 & $/ /$ & 81,95 & $/ /$ \\
\hline Ukupno & 3.551 & 2.026 & 57,05 & 1.054 & 29,68 & 471 & 13,26 \\
\hline
\end{tabular}

AMŽG, Baza podataka „Žrtve rata 1941-1945“

Žene stradale u logoru su predstavljale apsolutno dominantnu grupu u odnosu na muškarce, bez obzira iz kog dela okupirane Srbije su poticale, ali su

\footnotetext{
${ }^{31}$ Polovinu stradalih u logoru 1941. činila su deca uzrasta do 14 godina, a četvrtinu osobe stare 74 i više godina.
} 
imale različita učešća. Tako su Jevrejke iz Beogradskog regiona činile tri četvrtine gubitaka ovog regiona stradalih na Sajmištu, dok su osobe ženskog pola iz druga dva dela okupirane teritorije predstavljale po četiri petine njihovih gubitaka. Zastupljenost muškaraca u gubicima Jevreja koji su poticali iz Beogradskog regiona bila je neznatno veća (1,07 puta) od zastupljenosti osoba muškog pola u gubicima banatskih Jevreja i 1,27 puta veća od učešća muškaraca među žrtvama sunarodnika iz ostalog dela okupirane Srbije.

Apsolutna dominacija žena među žrtvama Judenlagera Semlin odredila je udele Jevreja iz različitih delova okupirane Srbije u ukupnim gubicima. Male razlike u udelu su postojale kod muškaraca iz različitih delova okupirane teritorije, pa su tako beogradski Jevreji imali neznatno veći udeo, banatski izjednačen, dok je udeo u gubicima muškaraca Jevreja iz ostalog dela okupirane Srbije bio manji $(1,21$ puta) od prosečnog udela stradalih ovog regiona u ukupnim gubicima u logoru.

Oformljen kao centralno mesto konačnog rešavanja jevrejskog pitanja u okupiranoj Srbiji, Judenlager Semlin je imao logoraše svih uzrasta. Pojedinačno najbrojniju grupu među stradalima, sa učešćem većim od četvrtine gubitaka, predstavljala su deca do 14 godina starosti. ${ }^{32}$ Sličnu zastupljenost $(23,70 \%)$ imale su i dve demografski najpotentnije uzrasne grupe koje su obuhvatale osobe od 15 do 34 godina. Pošto su kao narod uništavani u celini, drugu polovinu gubitaka u logoru predstavljali su Jevreji u dobi 35 i više godina.

Tabela 20: Logor Zemun Sajmište, Jevreji-starosna struktura prema polnoj pripadnosti

\begin{tabular}{|c|c|c|c|c|c|}
\hline $\begin{array}{c}\text { Jevreji OS, logor } \\
\text { Zemun - uzrast }\end{array}$ & Ukupno & Muškarci & $\%$ & Žene & $\%$ \\
\hline do 14 & 919 & 480 & 52,23 & 439 & 47,77 \\
\hline$\%$ & 28,44 & 66,85 & $/ /$ & 17,47 & $/ /$ \\
\hline 15 do 24 & 371 & 32 & 8,62 & 339 & 91,38 \\
\hline$\%$ & 11,48 & 4,46 & $/ /$ & 13,49 & $/ /$ \\
\hline 25 do 34 & 395 & 1 & 0,25 & 394 & 99,75 \\
\hline$\%$ & 12,22 & 0,14 & $/ /$ & 15,68 & $/ /$ \\
\hline 35 do 44 & 492 & 6 & 1,22 & 486 & 98,78 \\
\hline$\%$ & 15,23 & 0,83 & $/ /$ & 19,34 & $/ /$ \\
\hline 45 do 54 & 385 & 11 & 2,86 & 374 & 97,14 \\
\hline$\%$ & 11,91 & 1,53 & $/ /$ & 14,88 & $/ /$ \\
\hline 55 do 64 & 314 & 36 & 11,46 & 278 & 88,54 \\
\hline$\%$ & 9,72 & 5,01 & $/ /$ & 11,06 & $/ /$ \\
\hline 65 i više & 355 & 152 & 42,82 & 203 & 57,18 \\
\hline$\%$ & 10,99 & 21,17 & $/ /$ & 8,08 & $/ /$ \\
\hline
\end{tabular}

\footnotetext{
${ }^{32} \mathrm{Na}$ osnovu oskudno sačuvane arhivske građe moguće je delimično sagledati starosnu strukturu u logoru. Tako je 6. februara 1942. u logoru bilo 21,44\% dece mlađe od 16 godina, deset dana kasnije njihovo učešće bilo je 22,50\%, a 27. aprila 20,60\%. M. Koljanin, Nemački logor na Beogradskom sajmištu, 62. Iz postojeće dokumentacije nemoguće je uvideti koliko je dece umrlo u prethodnom periodu ili bilo prebačeno u Jevrejsku bolnicu u Beogradu.
} 


\begin{tabular}{|c|c|c|c|c|c|}
\hline Ukupno poznata & 3.231 & 718 & 22,22 & 2.513 & 77,77 \\
\hline \hline Nepoznata & 320 & 59 & 18,44 & 261 & 81,56 \\
\hline$\%$ & 9,01 & 7,59 & $/ /$ & 9,41 & $/ /$ \\
\hline Ukupno & 3.551 & 777 & 21,88 & 2.774 & 78,12 \\
\hline \multicolumn{7}{c}{ AMŽG, Baza podataka „Žrtve rata 1941-1945“ } \\
\hline
\end{tabular}

Formiranje logora na Beogradskom sajmištu nakon eliminacije većeg dela muške populacije u okviru jevrejskog nacionalnog korpusa uslovilo je drugačiju starosnu strukturu stradalih Jevreja različitog pola. Dve trećine muškaraca stradalih u logoru činila su deca do 14 godina starosti, uz petinu gubitaka koju su predstavljali stariji od 65 godina. Svega osminu gubitaka muškaraca u logoru predstavljale su osobe dobi između 15 i 64 godina starosti $(11,97 \%)$, s time što su u uzrasnoj grupi 55 do 64 godina starosti 88,89\% predstavljali muškarci stariji od 60. Muškarci Jevreji od 15 i više godina predstavljali su 7,37\% ukupnih žrtava Judenlagera Semlin. ${ }^{33}$ Za razliku od muškaraca, zastupljenost različitih uzrasnih grupa u gubicima žena bila je mnogo uravnoteženija i odgovarala je starosnoj strukturi celokupne jevrejske zajednice. Devojčice do 14 godina starosti predstavljale su šestinu gubitaka žena, dok su osobe starije od 65 godina činile njihov dvanaesti deo. Zastupljenost ovih uzrasta u gubicima žena bila je 3,82 odnosno 2,82 puta manja nego kod muškaraca stradalih u logoru. Zato su, s druge strane, starosne grupe koje su obuhvatale osobe uzrasta od 15 do 64 godina bile 6,22 puta zastupljenije u gubicima kod žena $(74,45 \%)$ nego kod muškaraca $(11,97 \%)$.

Udeo u gubicima pojedinih uzrasnih grupa koje su imali različiti polovi u velikoj meri bio je određen apsolutnom dominacijom Jevrejki u gubicima logora na Sajmištu. One su predstavljale gotovo jedine žrtve u uzrastima od 25 do 54 godina. S druge strane, muškarci su imali nadpolovični udeo u gubicima uzrasta do 14 godina starosti $(2,35$ puta veći od zastupljenosti muškaraca u gubicima logora), a predstavljali su i dve petine gubitaka osoba starijih od 65 godina $(1,93$ puta veći udeo od zastupljenosti muškaraca u ukupnim gubicima u logoru).

Pošto su bili određeni za uništenje kao narod u celini, među Jevrejima u logoru na Beogradskom sajmištu bilo je predstavnika svih profesionalnih grupa koje su postojale u predratnom periodu. Vreme i okolnosti nastanka logora uticali su na profesionalnu strukturu logoraša. Gotovo dve trećine svih stradalih predstavljala su izdržavana lica kao apsolutno dominantna profesionalna grupa u gubicima, uz šestinu stradalih koji su bili učenici i studenti, ${ }^{34}$ uz jedanaesti deo koji su činili privrednici, dok je učešće ostalih profesionalnih grupa bilo manje.

\footnotetext{
${ }^{33}$ Prema sačuvanoj arhivskoj građi muškarci stariji od 16 godina na dan 16. februara 1942. predstavljali su $6 \%$ logoraša, da bi ih 27. aprila bilo svega 3,6\%. M. Koljanin, Nemački logor na Beogradskom sajmištu, 62. Iz postojeće dokumentacije nemoguće je utvrditi koliko je muškaraca umrlo u prethodnom periodu ili bilo prebačeno u Jevrejsku bolnicu u Beogradu.

${ }^{34}$ Studenti (66) su među stradalim ove profesionalne grupe činili $12,72 \%$ gubitaka među učenicima i studentima.
} 
Tabela 21: Logor Zemun - Sajmište, Jevreji - profesionalna struktura prema polnoj pripadnosti

\begin{tabular}{|c|c|c|c|c|c|}
\hline $\begin{array}{l}\text { Jevreji OS, logor } \\
\text { Zemun - profesije }\end{array}$ & Ukupno & Muškarci & $\%$ & Žene & $\%$ \\
\hline poljoprivrednici & 9 & 3 & 33,33 & 6 & 66,67 \\
\hline$\%$ & 0,28 & 0,41 & $1 /$ & 0,24 & /1 \\
\hline privrednici & 293 & 146 & 49,83 & 147 & 50,17 \\
\hline$\%$ & 9,15 & 19,78 & $1 /$ & 5,96 & $1 /$ \\
\hline radnici & 75 & 16 & 21,33 & 59 & 78,67 \\
\hline$\%$ & 2,34 & 2,17 & // & 2,39 & // \\
\hline vojska, policija & - & - & - & - & - \\
\hline$\%$ & - & - & // & - & $/ /$ \\
\hline službenici, struč. & 209 & 41 & 19,62 & 168 & 80,38 \\
\hline$\%$ & 6,52 & 5,56 & $1 /$ & 6,81 & $1 /$ \\
\hline slobodna profesija & 19 & 11 & 57,89 & 8 & 42,11 \\
\hline$\%$ & 0,59 & 1,49 & $/ /$ & 0,32 & $/ /$ \\
\hline izdržavana lica & 2.041 & 304 & 14,89 & 1.737 & 85,11 \\
\hline$\%$ & 63,72 & 41,19 & $/ /$ & 70,47 & $/ /$ \\
\hline đaci i studenti & 519 & 197 & 37,96 & 322 & 62,04 \\
\hline$\%$ & 16,20 & 26,69 & // & 13,06 & $/ /$ \\
\hline ostala zanimanja & 9 & 2 & 22,22 & 7 & 77,78 \\
\hline$\%$ & 0,28 & 0,27 & // & 0,28 & // \\
\hline lični prihodi & 23 & 16 & 69,56 & 7 & 30,44 \\
\hline$\%$ & 0,72 & 2,17 & // & 0,28 & // \\
\hline nezaposleni & 6 & 2 & 33,33 & 4 & 66,67 \\
\hline$\%$ & 0,19 & 0,27 & // & 0,16 & // \\
\hline ukup. poznat & 3.203 & 738 & 23,04 & 2.465 & 76,96 \\
\hline nepoz. zan. & 348 & 39 & 11,21 & 309 & 88,79 \\
\hline$\%$ & 9,80 & 5,02 & // & 11,14 & // \\
\hline Ukupno & 3.551 & 777 & 21,88 & 2.774 & 78,12 \\
\hline
\end{tabular}

AMŽG, Baza podataka „Žrtve rata 1941-1945“

Vreme formiranja Judenlagera Semlin, nakon okončanja početne faze holokausta u okupiranoj Srbiji u kojoj je stradala većina muškaraca jevrejske zajednice, bitno je uticalo na profesionalnu strukturu u njemu zatočenih logoraša različitog pola. Među stradalim ženama izdržavana lica su činila više od dve trećine gubitaka, uz osminu učenika i studenata. Izdražavana lica su predstavljala najbrojniju profesionalnu grupu i među stradalim muškarcima, ali sa učešćem od dve petine gubitaka, uz četvrtinu koju su činili učenici i studenti i petinu privrednici. Time su izdržavana lica među stradalim osobama ženskog pola bila 1,71 puta zastupljenija nego među muškarcima, dok su privrednici, kao i učenici i studenti imali 3,32 odnosno 2,04 puta veće učešće u gubicima muškaraca nego žena. ${ }^{35}$

35 Zastupljenost službenika i stručnjaka u gubicima žena bila je 1,22 puta veća nego u gubicima muškaraca, dok je učešće radnika u gubicima polova bilo izjednačeno ( 1,10 puta veće među ženama). 
Udeli u gubicima profesionalnih grupa koje su imali različiti polovi u velikoj meri su bili određeni apsolutnom dominacijom žena u gubicima Judenlagera Semlin, ali uz nekoliko izuzetaka. Veći od svog prosečnog udela u gubicima žene su imale među stradalim izdržavanim licima. Iako su žene u logoru bile četiri puta brojnije od muškaraca, udeo u gubicima privrednika je bio izjednačen, dok je udeo muškaraca bio veći među stradalim pripadnicima slobodnih profesija i lica sa ličnim prihodima (penzioneri). Veći od njihovog prosečnog udela u gubicima, ali dvostruko manji od žena, muškarci su imali i među stradalim poljoprivrednicima i učenicima i službenicima. ${ }^{36}$

U dva logora za Jevreje koje su Nemci formirali u Beogradu život je izgubilo $86,47 \%$ od svih stradalih pripadnika jevrejske zajednice sa okupirane teritorije i $89,73 \%$ stradalih na toj teritoriji, s time što je stradanje na Sajmištu bilo dvostruko veće nego u Topovskim šupama. Kao centralna mesta holokausta u okupiranoj Srbiji, logori Topovske šupe i Sajmište nisu imali jednaku ulogu u uništenju Jevreja iz različitih delova okupirane teritorije, kao ni uništenju različitih polova, starosti i profesija.

Tabela 22: Okupirana Srbija, Jevreji - uloga logora Topovske šupe i Sajmište u uništenju Jevreja prema njihovoj teritorijalnoj pripadnosti

\begin{tabular}{|c|c|c|c|c|c|c|c|}
\hline $\begin{array}{c}\text { Jevreji OS - } \\
\text { regioni }\end{array}$ & Ukupno & $\begin{array}{c}\text { Topovske } \\
\text { šupe }\end{array}$ & $\%$ & $\begin{array}{c}\text { Judenlager } \\
\text { Semlin }\end{array}$ & $\%$ & Ostalo & $\%$ \\
\hline Beogradski & 3.484 & 1.088 & 31,23 & 2.026 & 58,15 & 370 & 10,62 \\
\hline$\%$ & 55,71 & 58,59 & $/ /$ & 57,05 & $/ /$ & 43,73 & $/ /$ \\
\hline Banat & 1.782 & 693 & 38,89 & 1.054 & 59,15 & 35 & 1,96 \\
\hline$\%$ & 28,49 & 37,32 & $/ /$ & 29,68 & $/ /$ & 4,14 & $/ /$ \\
\hline Ostalih 8 & 988 & 76 & 7,69 & 471 & 47,67 & 441 & 44,63 \\
\hline$\%$ & 15,80 & 4,09 & $/ /$ & 13,26 & $/ /$ & 52,13 & $/ /$ \\
\hline Ukupno & 6.254 & 1.857 & 29,69 & 3.551 & 56,78 & 846 & 13,53 \\
\hline
\end{tabular}

AMŽG, Baza podataka „Žrtve rata 1941-1945“

Po tri petine stradalih Jevreja iz Beogradskog regiona i Banata izgubilo je živote u Jevrejskom logoru Zemun, dok je u Topovskim šupama stradalo dve petine Jevreja iz Banata i trećina iz Beograda. Od beogradskih Jevreja devetina je izgubila živote na nekom drugom mestu, dok je kod njihovih sunarodnika iz Banata stradanje van ova dva logora bilo minimalno. S druge strane, polovina Jevreja iz ostalog dela okupirane Srbije izgubila je život u Jevrejskom logoru u Zemunu, tek trinaestina u Topovskim šupama, dok ih je više od dve petine stradalo na nekom drugom mestu.

Beogradski Jevreji su predstavljali po tri petine gubitaka u logorima Topovske šupe i Sajmište, uz Jevreje iz Banata koji su činili dve petine odnosno

\footnotetext{
${ }^{36}$ Kod stradalih učenika i studenata muškog pola u logoru na Sajmištu radilo se isključivo o učenicima, pošto su svi studenti stradali u logoru bile žene.
} 
nešto manje od trećine stradalih u ovim logorima. U gubicima van ova dva logora, polovinu svih stradalih činili su Jevreji iz ostalih 8 regiona okupirane Srbije, sunarodnici iz Beogradskog regiona nešto više od dve petine gubitaka, dok je učešće u gubicima banatskih Jevreja bilo izuzetno malo, činivši njihov dvadeset četvrti deo.

Tabela 23: Okupirana Srbija, Jevreji - uloga logora Topovske šupe i Sajmište u uništenju polova

\begin{tabular}{|c|c|c|c|c|c|c|c|}
\hline $\begin{array}{c}\text { Jevreji OS } \\
\text { pol }\end{array}$ & Ukupno & $\begin{array}{c}\text { Topovske } \\
\text { šupe }\end{array}$ & $\%$ & $\begin{array}{c}\text { Judenlager } \\
\text { Semlin }\end{array}$ & $\%$ & Ostalo & $\%$ \\
\hline muškarci & 3.313 & 1.857 & 56,05 & 777 & 23,45 & 679 & 20,49 \\
\hline$\%$ & 52,97 & 100,0 & $/ /$ & 21,88 & $/ /$ & 80,26 & $/ /$ \\
\hline žene & 2.941 & - & - & 2.774 & 94,32 & 167 & 5,68 \\
\hline$\%$ & 47,02 & - & $/ /$ & 78,12 & $/ /$ & 19,74 & $/ /$ \\
\hline Ukupno & 6.254 & 1.857 & 29,69 & 3.551 & 56,78 & 846 & 13,53 \\
\hline
\end{tabular}

AMŽG, Baza podataka „Žrtve rata 1941-1945“

Topovske šupe i Sajmište su imali presudnu ulogu u brutalnom uništenju Jevreja oba pola u okupiranoj Srbiji. U njima su život izgubile skoro sve žene i četiri petina muškaraca od stradalih pripadnika jevrejske zajednice, s time što je u logoru Topovske šupe ubijeno dvostruko više muškaraca nego na Sajmištu. Devet desetina svih Jevreja muškaraca ubijenih 1941. godine stradalo je u Topovskim šupama, dok je od ubijenih 1942. godine $66,18 \%$ izgubilo živote na Sajmištu. Od stradalih Jevrejki 1942. godine 97,92\% je ubijeno u Jevrejskom logoru Zemun. Udeo Topovskih šupa u uništavanju muškaraca bio je 1,89 puta veći od udela žrtava logora u ukupnim gubicima jevrejske zajednice, udeo Judenlagera Zemun je bio 2,42 puta manji dok je, s druge strane, uloga Sajmišta u uništenju žena bila 1,66 puta veća od udela žrtava ovog logora u ukupnim gubicima Jevreja sa okupirane teritorije. U gubicima Jevreja okupirane Srbije van ova dva nemačka logora u Beogradu muškarci su bili 4,06 puta brojniji od žena i imali su 1,51 puta veći udeo od zastupljenosti stradalih van ova dva logora u ukupnim gubicima Jevreja okupirane teritorije, dok je udeo gubitaka žena bio 2,38 puta manji. ${ }^{37}$

Tabela 24: Okupirana Srbija, Jevreji - uloga logora Topovske šupe i Sajmište u uništenju starosnih grupa

\begin{tabular}{|c|c|c|c|c|c|c|c|}
\hline $\begin{array}{c}\text { Jevreji OS, }- \\
\text { uzrast }\end{array}$ & Ukupno & $\begin{array}{c}\text { Topovske } \\
\text { šupe }\end{array}$ & $\%$ & $\begin{array}{c}\text { Judenlager } \\
\text { Semlin }\end{array}$ & $\%$ & Ostalo & $\%$ \\
\hline do 14 & 972 & - & - & 919 & 94,55 & 53 & 5,45 \\
\hline$\%$ & 17,17 & - & $/ /$ & 28,44 & $/ /$ & 7,29 & $/ /$ \\
\hline 15 do 24 & 778 & 308 & 39,59 & 371 & 47,69 & 99 & 12,72 \\
\hline$\%$ & 13,74 & 18,10 & $/ /$ & 11,48 & $/ /$ & 13,62 & $/ /$ \\
\hline 25 do 34 & 932 & 392 & 42,06 & 395 & 42,38 & 145 & 15,56 \\
\hline
\end{tabular}

${ }^{37}$ Najveći deo muškaraca stradao je u logorima Crveni krst u Nišu (Anhaltelager Nisch) i Banjica u Beogradu (Anhaltelager Dedinje), kao i u streljanjima širom Srbije. 
Logori Topovske šupe i Sajmište kao centralna mesta holokausta...

\begin{tabular}{|c|c|c|c|c|c|c|c|}
\hline$\%$ & 16,47 & 23,03 & $/ /$ & 12,22 & $/ /$ & 19,94 & $/ /$ \\
\hline 35 do 44 & 1.095 & 443 & 40,46 & 492 & 44,93 & 160 & 14,61 \\
\hline$\%$ & 19,35 & 26,03 & $/ /$ & 15,23 & $/ /$ & 22,01 & $/ /$ \\
\hline 45 do 54 & 868 & 361 & 41,59 & 385 & 44,35 & 122 & 14,05 \\
\hline$\%$ & 15,33 & 21,21 & $/ /$ & 11,91 & $/ /$ & 16,78 & $/ /$ \\
\hline 55 do 64 & 599 & 198 & 33,05 & 314 & 52,42 & 87 & 14,52 \\
\hline$\%$ & 10,58 & 11,63 & $/ /$ & 9,72 & $/ /$ & 11,97 & $/ /$ \\
\hline 65 i više & 416 & - & - & 355 & 85,34 & 61 & 14,66 \\
\hline$\%$ & 7,35 & - & $/ /$ & 10,99 & $/ /$ & 8,39 & $/ /$ \\
\hline ukupno pozn. & 5.660 & 1.702 & 30,07 & 3.231 & 57,08 & 727 & 12,84 \\
\hline \hline nepoznata & 594 & 155 & 26,09 & 320 & 53,87 & 119 & 20,03 \\
\hline$\%$ & 9,50 & 8,35 & $/ /$ & 9,01 & $/ /$ & 14,07 & $/ /$ \\
\hline Ukupno & 6.254 & 1.857 & 29,69 & 3.551 & 56,78 & 846 & 13,53 \\
\hline
\end{tabular}

AMŽG, Baza podataka „Žrtve rata 1941-1945“

U Jevrejskom logoru Zemun stradali su gotovo svi pripadnici jevrejske zajednice mlađi od 14 godina, kao i šest sedmina starijih od 65 godina. Sa posebno ciljanim starosnim grupama koje su uništene u logoru Topovske šupe, udeo u gubicima uzrasta između 25 i 54 godina stradalih u ovom logoru (41,31\%) bio je 1,37 puta veći od udela žrtava logora u ukupnim gubicima, dok je $\mathrm{s}$ druge strane udeo Sajmišta u uništenju uzrasta do 14 godina i starijih od 65 bio 1,65 odnosno 1,49 puta veći od udela žrtava logora u ukupnim gubicima jevrejske zajednice. Jevreji stradali na ostalim mestima imali su neznatno povećane udele u gubicima uzrasta starijih od 25 godina u odnosu na njihov udeo u ukupnim gubicima, ali i 2,35 puta manji udeo kod stradalih uzrasta do 14 godina starosti.

Ciljano ubijanje Jevreja uzrasta 15 do 60 godina starosti u Topovskim šupama prouzrokovalo je da je zastupljenost starosnih grupa 15 do 54 godina u njihovim gubicima $(88,37 \%)$ bila 1,74 puta veća nego u gubicima na Sajmištu $(50,84 \%)$. Izuzev u najmlađoj uzrasnoj grupi kod koje je učešće u gubicima bilo 2,35 puta manje, sve ostale starosne grupe Jevreja stradalih van ova dva logora su imale zastupljenost jednaku prosečnom učešću u ukupnim gubicima.

Tabela 25: Okupirana Srbija, Jevreji - uloga logora Topovske šupe i Sajmište u uništenju profesionalnih grupa

\begin{tabular}{|c|c|c|c|c|c|c|c|}
\hline $\begin{array}{c}\text { Jevreji OS - } \\
\text { profesije }\end{array}$ & Ukupno & $\begin{array}{c}\text { Topovske } \\
\text { špe }\end{array}$ & $\%$ & $\begin{array}{c}\text { Judenlager } \\
\text { Semlin }\end{array}$ & $\%$ & Ostalo & $\%$ \\
\hline poljoprivrednici & 20 & 9 & 45,00 & 9 & 45,00 & 2 & 10,00 \\
\hline$\%$ & 0,36 & 0,53 & $/ /$ & 0,28 & $/ /$ & 0,29 & $/ /$ \\
\hline privrednici & 1.277 & 733 & 57,40 & 293 & 22,94 & 251 & 19,65 \\
\hline$\%$ & 22,92 & 43,45 & $/ /$ & 9,15 & $/ /$ & 36,80 & $/ /$ \\
\hline radnici & 323 & 187 & 57,89 & 75 & 23,22 & 61 & 18,88 \\
\hline$\%$ & 5,80 & 11,08 & $/ /$ & 2,34 & $/ /$ & 8,94 & $/ /$ \\
\hline vojska, policija & 2 & 1 & 50,00 & - & -- & 1 & 50,00 \\
\hline
\end{tabular}




\begin{tabular}{|c|c|c|c|c|c|c|c|}
\hline$\%$ & 0,03 & 0,06 & $/ /$ & - & $/ /$ & 0,15 & $/ /$ \\
\hline služb., struč. & 767 & 436 & 56,84 & 209 & 27,25 & 122 & 15,91 \\
\hline$\%$ & 13,76 & 25,84 & $/ /$ & 6,52 & $/ /$ & 17,89 & $/ /$ \\
\hline slob. profesija & 106 & 58 & 54,72 & 19 & 17,92 & 29 & 27,36 \\
\hline$\%$ & 1,90 & 3,44 & $/ /$ & 0,59 & $/ /$ & 4,25 & $/ /$ \\
\hline izdržavana lica & 2.201 & 29 & 1,32 & 2.041 & 92,73 & 131 & 5,95 \\
\hline$\%$ & 39,51 & 1,72 & $/ /$ & 63,72 & $/ /$ & 19,21 & $/ /$ \\
\hline đaci i studenti & 804 & 211 & 26,24 & 519 & 64,55 & 74 & 9,20 \\
\hline$\%$ & 14,43 & 12,51 & $/ /$ & 16,20 & $/ /$ & 10,85 & $/ /$ \\
\hline ostala zanimanja & 23 & 9 & 39,13 & 9 & 39,13 & 5 & 21,74 \\
\hline$\%$ & 0,41 & 0,53 & $/ /$ & 0,28 & $/ /$ & 0,73 & $/ /$ \\
\hline lični prihodi & 37 & 10 & 27,03 & 23 & 62,16 & 4 & 10,81 \\
\hline$\%$ & 0,66 & 0,59 & $/ /$ & 0,72 & $/ /$ & 0,59 & $/ /$ \\
\hline nezaposleni & 12 & 4 & 33,33 & 6 & 50,00 & 2 & 16,67 \\
\hline$\%$ & 0,21 & 0,24 & $/ /$ & 0,19 & $/ /$ & 0,29 & $/ /$ \\
\hline ukupno poznato & 5.572 & 1.687 & 30,28 & 3.203 & 57,48 & 682 & 12,24 \\
\hline \hline nepoznata zan. & 682 & 170 & & 348 & & 164 & 24,05 \\
\hline$\%$ & 10,90 & 9,15 & $/ /$ & 9,80 & $/ /$ & 19,38 & $/ /$ \\
\hline Ukupno & 6.254 & 1.857 & 29,69 & 3.551 & 56,78 & 846 & 13,53 \\
\hline
\end{tabular}

AMŽG, Baza podataka „Žrtve rata 1941-1945“

Analiza gubitaka prema profesionalnoj strukturi Jevreja ${ }^{38}$ pokazuje da su u holokaustu stradali pripadnici svih profesionalnih grupa. Opredeljenost Nemaca da u početnoj fazi holokausta pobiju muškarce uzrasta 15 do 60 godina, a kasnije preostale Jevreje odrazila se na profesionalnu strukturu stradalih u logorima. Tako je u Topovskim šupama stradalo po tri petine privrednika, radnika, službenika i stručnjaka, što je bio gotovo dvostruko veći udeo u gubicima ovih profesionalnih

38 Približno sagledavanje socijalno-ekonomske strukture Jevreja okupirane Srbije moguće je preko sagledavanja iste $\mathrm{u}$ jugoslovenskim okvirima, s time što treba uzeti u obzir uticaj Beograda kao administrativnog, političkog, ekonomskog, prosvetnog, kulturnog centra države na profesionalnu strukturu populacije, posebno Jevreja, od kojih je najveći deo živeo u njemu. Prema nepotpunim podacima iz 1938. godine u Jevrejskoj zajednici Jugoslavije bilo je 0,15\% poljoprivrednika, $12,60 \%$ privrednika, 4,30\% radnika, 8,05\% službenika, stručnjaka i pripadnika slobodnih profesija, 10,30\% učenika i studenata i 64,60\% svih drugih zanimanja. D. Perera, „Neki statistički podaci o Jevrejima“, 145-146. Poreske obaveze u verskim opštinama daju delimičan uvid u profesionalnu strukturu beogradskih Jevreja 1940. godine, uz napomenu da su porez plaćali samo imućniji, odnosno oni koji su se kvalifikovali. Među 2.002 poreska obveznika sefardske opštine $27 \%$ su bili trgovci, $21 \%$ činovnici ili nameštenici, $8 \%$ zanatlije, $4 \%$ lekari i inženjeri. Od 1.091 obveznika aškenaske opštine $25 \%$ su bili činovnici, 20\% trgovci, 8\% pripadnici slobodnih profesija, 6\% zanatlija. Harijet Pas Frajdenrajh, „Jevreji Beograda između ratova“, Jevrejski istorijski muzej Zbornik, 6, (1992), 366. Na teritoriji Uprave grada Beograda 1939. godine bilo je 346 zanatlija, 1.102 trgovca, trgovačkih agenata i putnika, 70 industrijalaca, 24 bankara i menjača, dok je u Moravskoj banovini bilo 18 zanatlija, 43 trgovca, 3 industrijalca, 6 bankara. Небојша Поповић, Јевреји у Србији 1918-1941 (Београд: ИСИ, 1997), 103. 
grupa od udela žrtava ovog logora u ukupnim gubicima Jevreja, dok je udeo u njemu stradalih izdržavanih lica bio 22,94 puta manji. S druge strane, u Jevrejskom logoru Zemun život je izgubilo devet desetina izdržavanih lica, što je bio 1,61 puta veći udeo u gubicima ove profesionalne grupe od zastupljenosti žrtava ovog logora u ukupnim gubicima jevrejske zajednice, a i udeo u njemu stradalih učenika i studenata bio je 1,12 puta veći, ${ }^{39}$ dok je udeo svih ostalih profesionalnih grupa bio višestruko manji (službenika i stručnjaka 2,11 puta, privrednika 2,50 puta, slobodnih profesija 3,21 puta). Među stradalima van ova dva logora, udeo privrednika, radnika, službenika i stručnjaka, te pripadnika slobodnih profesija i vojske i policije bio je veći od njihovog udela u ukupnim gubicima Jevreja.

Različita polna i starosna struktura stradalih u logorima Topovske šupe i Sajmište uslovila je i drugačiju zastupljenost profesionalnih grupa u njihovim gubicima. Tako su privrednici, radnici, službenici i stručnjaci među stradalima u Topovskim šupama $(80,37 \%)$ bili 4,46 puta zastupljeniji nego u gubicima Jevrejskog logora Zemun $(18,01 \%)$, dok su izdržavana lica među stradalima na Sajmištu bila 37,05 puta zastupljenija nego u gubicima u Topovskim šupama, a učenici i studenti 1,29 puta. ${ }^{40}$ Među stradalima na drugim mestima učešće privrednika, radnika, službenika i stručnjaka $(63,63 \%)$ bilo je 1,50 puta veće od prosečne zastupljenosti ovih profesija u ukupnim gubicima Jevreja (42,48\%), dok je učešće izdržavanih lica bilo dvostruko manje.

Holokaust na teritoriji okupirane Srbije, kao deo jedinstvenog procesa u Evropi, pogodio je čitavu jevrejsku zajednicu nanevši joj nenadoknadive gubitke. Nažalost, do sada nije utvrđen precizan broj u holokaustu stradalih Jevreja sa teritorije okupirane Srbije, kao što nije poznat ni broj preživelih. ${ }^{41} \mathrm{U}$ literaturi je najčešće navođena procena od 13.600 stradalih $^{42}$ ( $82 \%$ predratne populacije).

${ }^{39}$ Studenti (192) su predstavljali 23,88\% svih stradalih učenika i studenata. Među svim stradalim studentima jevrejske nacionalnosti bilo je $63,54 \%$ muškaraca i $36,44 \%$ žena. Od svih ubijenih studenata $46,87 \%$ je izgubilo živote u Topovskim šupama, $34,37 \%$ na Sajmištu i $18,76 \%$ na ostalim mestima van ova dva logora (36). Time je udeo studenata stradalih u logoru Topovske šupe bio 1,55 puta veći od udela žrtava logora u ukupnim gubicima, dok je udeo stradalih studenata na Sajmištu bio 1,62 puta manji.

${ }^{40}$ Učešće studenata u gubicima u logoru Topovske šupe bilo je 1,36 puta veće nego na Sajmištu.

${ }^{41}$ Nepoznato je koliko je preživelih Jevreja sa teritorije koju je zauzimala okupirana Srbija. Prema podacima od 27. septembra 1946. sa teritorije tzv. uže Srbije preživela su 2.422 Jevreja, a njima treba pridodati i onaj deo preživelih sa teritorije AP Vojvodine (3.729) koji je poticao iz Banata, da bi se približno dobio uvid u broj preživelih za teritoriju koja je približno jednaka teritoriji okupirane Srbije. D. Perera, „Neki statistički podaci o Jevrejima u Jugoslaviji“, 136. Naravno, ove podatke treba uzeti sa kritičkom distancom, pošto svi posle rata u Srbiji prijavljeni Jevreji nisu nužno bili i njeni stanovnici u predratnom periodu, što otvara mogućnost manjih odstupanja. S druge strane, treba imati u vidu da se svi preživeli Jevreji nisu vratili u Srbiju, već da je deo direktno otišao za Palestinu odnosno kasnije formiranu državu Izrael, a da je deo ostao i nastavio, odnosno otpočeo, život u evropskim ili prekookeanskim zemljama. Opširnije o repatrijaciji Jevreja u posleratnom periodu videti u: Mladenka Ivanović, Jevreji u Jugoslaviji (19441952), Kraj ili novi početak (Beograd: INIS, 2009).

${ }^{42}$ Oko procena broja stradalih opširnije videti M. Koljanin, Nemački logor na Beogradskom sajmištu, 128-131. Na osnovu dosadašnjih saznanja o holokaustu na teritoriji okupirane Srbije, mišljenja sam da bi trebalo ponovo otvoriti pitanje broja stradalih Jevreja sa ove teritorije. Kao polaznu osnovu tre- 
Među stradalim civilima okupirane Srbije Jevreji su predstavljali 11,20\% gubitaka, ${ }^{43}$ dok su u predratnom stanovništvu ove teritorije činili svega $0,33 \%$, tako da je u holokaustu uništena jevrejska zajednica pretrpela gubitke 33,94 puta veće od njihove zastupljenosti u populaciji. Holokaust na teritoriji okupirane Srbije je bio tesno povezan sa logorima Topovske šupe i Sajmište u kojima je život izgubilo $86,47 \%$ od svih stradalih pripadnika jevrejske zajednice sa ove teritorije, uz ubijene Jevreje sa drugih područja Jugoslavije, kao i inostranstva. U njima je ubijeno $79,51 \%$ od svih stradalih muškaraca jevrejske zajednice okupirane Srbije, dok je na Sajmištu život izgubilo 94,32\% od svih stradalih Jevrejki. Dok su u Topovskim šupama žrtve bili muškarci uzrasta 15 do 60 godina starosti različitih profesija $(80,37 \%$ su bili privrednici, radnici i službenici i stručnjaci), u Jevrejskom logoru Zemun život su gubili pripadnici jevrejske zajednice svih uzrasta $(28,44 \%$ činila su deca do 14 godina, a $10,90 \%$ osobe od 65 i više godina) i svih profesionalnih grupa $(63,72 \%$ činila su izdržavana lica). Analiza unutrašnje strukture pretrpljenih gubitaka Jevreja pokazuje da su ova dva logora predstavljala centralno mesto holokausta u okupiranoj Srbiji koji nije poštedeo nijedan segment jevrejske zajednice.

ba uzeti neospornu činjenicu da su Jevreji uništavani kao narod u celini, bez obzira na njihovu pol i dob, te da je stradalo približno jednako muškaraca i žena svih uzrasta, odnosno da je broj stradalih osoba ženskog pola bio neznatno manji. Sva dosadašnja istraživanja ukazuju na to da je stradanje Jevrejki sa okupirane teritorije bilo vezano za logor na Sajmištu (Judenlager Semlin). Značajniji broj stradalih osoba ženskog pola jevrejske nacionalnosti zabeležen je još u Jevrejskoj bolnici u Beogradu (polovina od 300 do 400 bolesnika dopremljenih iz drugih bolnica, lekara, osoblja i članova njihovih porodica, kasnije dopremljeni bolesni logoraši sa Sajmišta brojani su kao žrtve logora) i u logoru na Banjici (više desetina, svakako ne više od 120 žena - kada se od ukupnog broja Jevreja stradalih na Banjici odbiju strani državljani i Jevreji jugoslovenski državljani koji su u logor dovedeni sa teritorija van okupirane Srbije, Jevrejke sa okupirane teritorije su predstavljale četvrtinu sunarodnika stradalih u logoru). Prema najpreciznijem i najpotpunijem istraživanju o stradanju u Jevrejskom logoru u Zemunu, kolege Milana Koljanina (M. Koljanin, Nemački logor na Beogradskom sajmištu, 59, 62, 131), broj stradalih je bio 6.320. Da bismo došli do broja stradalih Jevrejki iz okupirane Srbije, od tog broja treba oduzeti broj od 400 stranih državljana (266 prema novijem istraživanju - Isti, „Poslednje putovanje Kladovskog transporta“, Kladovo transport, 90), zatim najmanje 332 muškarca starijih od 16 godina, te najmanje 619 dečaka (polovina dece do 16 godina starosti), što dovodi do broja od 4.969 odnosno 5.103. Zajedno sa stradalim ženama iz Jevrejske bolnice, sa Banjice i pojedinačno ili u manjim grupama stradalih u neuspelim pokušajima pronalaženja utočišta na drugim teritorijama, broj stradalih Jevrejki sa teritorije okupirane Srbije bio je oko 5.500. Pošto su žene predstavljale gotovo polovinu pretrpljenih gubitaka, ukupan broj u holokaustu stradalih Jevreja sa teritorije okupirane Srbije kreće se između 11.400 i 11.700, svakako ne više od 12.000. Buduća istraživanja ili pojava novih dokumenata potvrdiće ili odbaciti ovo mišljenje.

${ }^{43}$ Do sada je u procesu revizije popisa „Žrtve rata 1941-1945” utvrđen broj od 55.830 stradalih civila sa teritorije okupirane Srbije. 


\section{REFERENCE}

- Bauer, Yehuda. „Is the Holocaust explicable“. U: Izraelsko-srpska naučna razmena u proučavanju holokausta/Israeli-Serbian academic exchange in Holocaust research. Urednik Jovan Mirković, 147-167. Beograd: Muzej žrtava genocida, 2008.

- Cvetković, mr Dragan. „Gubici pripadnika partizanskog pokreta sa teritorije Jugoslavije 1941-1945“. Doktorska disertacija, Univerzitet u Beogradu, Filozofski fakultet, Odeljenje za istoriju, 2016.

- Ćulibrk, Jovan. Istoriografija holokausta u Jugoslaviji. Beograd: PBF i ITI, 2011.

- Definitivni rezultati popisa stanovništva od 31. marta 1931. godine, knjiga II, Prisutno stanovništvo prema veroispovesti, Beograd: Državna štamparija, 1938.

- Frajdenrajh, Harijet Pas. „Jevreji Beograda između ratova“. Jevrejski istorijski muzej Zbornik, br. 6, (Beograd, 1992), 365-371.

- Ivanović, Mladenka. Jevreji u Jugoslaviji (1944-1952), Kraj ili novi početak. Beograd: INIS, 2009.

- Koljanin, Milan. Nemački logor na Beogradskom sajmištu 1941-1944. Beograd: ISI, 1992.

- Koljanin, Milan. „Istraživanje holokausta u Jugoslaviji“. U: Izraelsko-srpska naučna razmena u proučavanju holokausta / Israeli-Serbian academic exchange in Holocaust research. Urednik Jovan Mirković, 264-273. Beograd: Muzej žrtava genocida, 2008.

- Koljanin, Milan. „Poslednje putovanje Kladovskog transporta“. U: Kladovo transport / The Kladovo transport, Zbornik radova. Urednik Andrej Mitrović, 65-101. Beograd: JIM, 2006.

- Koljanin, Milan. „Represija kao sistem - logori u okupiranoj Srbiji“. Heretikus, br. 1, (2007), 157-171.

- Mitrović, Andrej, ur. Kladovo transport / The Kladovo transport, Zbornik radova sa okruglog stola. Beograd: JIM, 2006.

- Prpa, Branka, gl. i odg. ur. Logor Banjica, Logoraši, objavljeni izvori. Beograd: Istorijski arhiv Beograda, 2009.

- Ristović, Milan. U potrazi za utočištem, Jugoslovenski Jevreji u bekstvu od holokausta 1941-1945. Beograd: Službeni list SRJ, 1998.

- Ristović, Milan. „Jugoslavija i jevrejske izbeglice 1938-1941“. Istorija 20. veka, br. 1, (1996), 21-43.

- Perera, David. „Neki statistički podaci o Jevrejima u Jugoslaviji u periodu od 1938. do 1965. godine“. Jevrejski almanah 1968-1970, (Beograd, 1971).

- Žarković, Nenad. „Prolazni logor Topovske šupe“. Nasleđe, br. 10, (2009), 103-112.

- Žrtve rata 1941-1945 (rezultati popisa), Beograd: Savezni zavod za statistiku, 1966, reprint izdanje, Beograd: Savezni zavod za statistiku, 1992. 
DRAGAN CVETKOVIĆ, PhD, Museum Adviser

Museum of Genocide Victims

Belgrade, Republic of Serbia

vecadzigy@yahoo.com

CAMPS TOPOVSKE ŠUPE AND SAJMIŠTE AS CENTRAL

PLACES OF THE HOLOCAUST IN OCCUPIED SERBIA -

NUMERICAL DETERMINATION AND QUANTITATIVE ANALYSIS

\section{Summary}

The paper is an attempt to show the central role of Topovske šupe camp and Judenlager Semlin in the destruction of the Jewish community in Occupied Serbia based on the partially revised list „Victims of War 1941-1945“. The article deals with the territorial belonging of the killed Jews, the gender, age and professional structure of their losses in these two camps, and shows the share of losses from these two camps in the total losses of the Jewish community.

As part of a unique process in Europe, the Holocaust on the territory of Occupied Serbia has hit the entire Jewish population, inflicting irreparable losses. Unfortunately, no precise number has been established in the Holocaust of the stricken Jews from the territory of Occupied Serbia, as the number of survivors is unknown. The most frequently quoted estimate is $13.600(82 \%$ of their pre-war number). Among the dead civilians of the Occupied Serbia Jews accounted for $11.20 \%$ of losses, while in the pre-war population of this territory only $0.33 \%$ were incurred, so the Jewish community suffered losses in the Holocaust 33.94 times more than their representation in the population. The Holocaust in the territory of Occupied Serbia was closely linked to the Topovske šupe camps and Sajmište camps (Judenlager Semlin), where $86.47 \%$ of all killed members of the Jewish community from this territory lost their lives, alongside with killed Jews from other parts of Yugoslavia as well as abroad. In those two camps $79.51 \%$ of all male victims of the Jewish community of occupied Serbia were killed, while $94.32 \%$ of all female victims were killed in Sajmište. While in the Topovske šupe victims were men aged 15 to 60 years of different professions $(80.37 \%$ were businessmen, workers, officials and experts), were members of the Jewish community executed in the Judenlager Semlin were of all ages $(28.44 \%$ were children under 14 and $10.90 \%$ were person older than 65$)$ and all professional groups (63.72\% were dependent persons). An analysis of the internal structure of the suffered losses of the Jews shows that these two camps represented the central place of the Holocaust in Occupied Serbia that did not spare any segment of the Jewish community.

KEYWORDS: Holocaust, Jews, Occupied Serbia, regions, gender, age and professional structure, concentration camps, Topovske šupe, Sajmište 